\title{
Vibration Control of Resonant Vibratory Feeders With Electromagnetic Excitation
}

Željko V. Despotović

PhD.E.E, Senior Research Associate Institute "Mihajlo Pupin" University of Belgrade

Milan Lečić

Full professor University of Belgrade Faculty of Mechanical Engineering

Milan R. Jović PhD student University of Belgrade Faculty of Electrical Engineering Teaching Assistant

School of Electrical and Computer Engineering of Applied Studies, Belgrade

Ana Djuric

Assistant Professor, Engineering Technology Wayne State University Detroit, M USA

The vibratory feeders with electromagnetic excitation called electromagnetic vibratory feeders (EMVF) are commonly used for performing gravimetric flow of granular and particulate materials in processing industry. This drives offer easy and simple control the mass flow of conveying materials. In comparison with other drives (pneumatics, inertial, centrifugal, etc...), these have a more simple construction and they are compact, robust and reliable in operation. The absence of wearing mechanical part, such as gears, cams belts, bearings, eccentrics, etc., makes EMVF, most economical equipment. Standard power electronic output stages intended for control of theEMVF using SCR devices (thyristors and triacs). This implies phase angle control (PAC) and constant frequency of vibration. In this way control circuit must be synchronized to the mains supply frequency 50(60) Hz. PAC can only accomplish tuning amplitude of vibration, but not vibratory frequency. Application of transistor (IGBT or MOSFET) switch mode power converters enables accomplishing the amplitude and (or) frequency control of EMVF. Their use implies the excitation of an EMVF independent of the mains supply frequency. In addition, the frequency control ensures operation in the region of mechanical resonance. This operation is highly efficient, because large output displacement is provided by small input power. An optimal and efficient operation requires tracking of resonant frequency. This paper presents possible solution of the amplitudefrequency control of EMVF and corresponding simulation and experimental results.

Keywords: Vibration control, vibratory feeder, mechatronics, electromagnetic drive, resonance, power electronics, power converter, SCR, IGBT, power control

\section{INTRODUCTION}

The vibration energy has proved, for many years its operational reliability in various technological processes: discharging bulk materials from bins, conveying them over limited distances, charging and dosing them continuously, compacting, loosening, screening, grading them (including dedusting and dewatering)...etc. From the macroscopic point of view, the process of vibratory processing is based on microthrows of particles of the material. Therefore the material obtains character of a "viscous fluid" and thus becomes suitable for conveying or further processing [1-5]. Vibratory feeders with electromagnetic excitation (drive) are used extensively in controlling the discharge of bulk solids from bins and stockpiles. Electromagnetic drives offer step-less, accurate and repeatable setting of the oscillation amplitude, a long life (absence of wearing mechanical part, such as gears, cams belts, bearings, eccentrics i.e. they have no rotating parts), and

Received: May 2014, Accepted: October 2014

Correspondence to: Dr Željko V. Despotović

Mihailo Pupin Institute,

Volgina 15, 11060 Belgrade, Serbia

E-mail: zeljko.despotovic@pupin.rs

doi:10.5937/fmet1404281D

(C) Faculty of Mechanical Engineering, Belgrade. All rights reserved they reach the desired amplitude immediately upon switching on, and they come to a rest after being turned off in very short time (several milliseconds).

The design of the vibratory feeder with electromagnetic excitation i.e. electromagnetic vibratory feeder (EMVF) is based on a system of two masses coupled by means of an elastic component consisting of flexible leaf composite springs (commonly Fiberglass $^{\mathrm{TM}}$ ). The quantity of leaf springs fitted up determines the resonant operation of the equipment. A driving electrical current excites the magnetic core, attracting the moving armature, which is attached to the load carrying element (LCE) of EMVF i.e. vibratory trough. The energy accumulated in the leaf springs is used to return the system to its position of equilibrium. By realizing free vibrations of variable amplitude and frequency, over a wide range application of the twomass oscillatory system, suitable power converter and the corresponding controller, continuous conveyance and dosing of granular materials have been provided for various operating conditions. In this way, the whole system power converter-power controller-vibratory actuator-vibratory feeder i.e. regulated vibratory conveying drive, has behavior of the controllable mechanical oscillator [6-9]. 
By applying sophisticated vibration control based on adjusting the amplitude of oscillation and tracking/tuning the resonant frequency, it is possible to accomplish the operation the entire mechanical system in the resonance range. Operation of EMVF in the mechanical resonant range becomes favorable, because the final values of the oscillation amplitude can be obtained for relatively small energy of excitation. Operation in this region is the most energy efficient, since then, the entire vibratory drive has minimal power consumption [10].

Standard power output stages intended for vibration control of EMVF, using SCR devices (thyristors and triacs), imply the use of phase angle control. Since the supply network frequency is constant $(50 \mathrm{~Hz} / 60 \mathrm{~Hz})$, the adjusting of phase angle can only accomplished control of the amplitude oscillations, but not and their frequency [6-7], [9]. Application of switch mode IGBT power converters enables accomplishing the amplitude and/or frequency control of EMVF [11-13]. Their use makes the excitation of EMVF independent of the supply network frequency. In addition, the control of frequency ensures operation of vibratory feeder in the region of mechanical resonance.

\section{THE CONSTRUCTION OF RESONANT ELECTROMAGNETIC VIBRATORY FEEDER}

There is a wide range of design and variety constructions of EMVF currently available that are in some way flexible. The basic construction and mechatronic design of flexible vibratory feeding systems are available in literature [14-16]. This paper is interested in the construction of linear resonant EMVF.

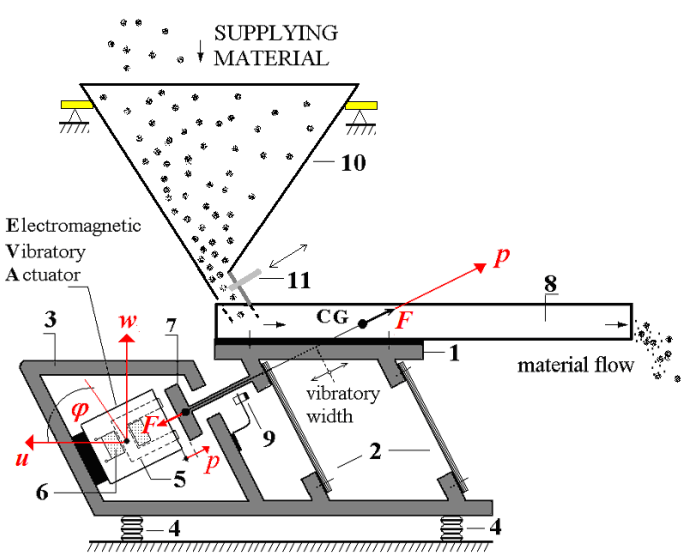

Figure 1. Typical construction of resonant EMVF

A typical arrangement of resonant EMVF is presented in Figure 1. Its main components are: load carry element (LCE) -1, electromagnetic vibratory actuator (EVA) as source of excitation force $F$ and flexible elements -2. Flexible elements are made of composite leaf (Fiberglass) springs. These elements are rigidly connected with the LCE on the one side, while, on the other side, they are fitted to the base- 3 of the device and sloped down under certain angle. The base of vibratory conveyor is resting on rubber pads- 4 to the foundation. EVA consists of a magnetic core-5, covered by continuous windings coil-6. As the ferromagnetic material has a very high permeability, all energy of the magnetic field is stored in air gap of the actuator. Created magnetic field which produce the electromagnetic force $F$ acts on armature-7 attached to the LCE. This element carries the vibratory trough- 8 along with conveying material. The vibratory displacement between base-3 and LCE -1 is detected by a non contact inductive sensor -9 . The material which is dosed is brought to the LCE from a storage hopper - 10 . Adjustment of the material inflow is accomplished by a movable shutter - 11 which is placed at the bottom of the hopper.

\section{THE DYNAMIC MODEL OF RESONANT ELECTROMAGNETIC VIBRATORY FEEDER}

To define the control strategy of the vibratory conveyor, it is required to analyze the electromagnetic and mechanical parts of the system. Detailed dynamic model of EMVF is presented in [6-7], [16] and [16-17]. In general vector form, this model can be represented as:

$$
M \cdot \ddot{z}+C \cdot \dot{z}+K \cdot z=\Gamma \cdot F .
$$

Vector $z \in R^{4} \wedge z=\left[\begin{array}{llll}p & w & u & \varphi\end{array}\right]^{T}$ represents position vector and it contains the relative displacement $p$, of the LCE with respect to the base, displacements of the base $u, w$ in the horizontal and vertical directions respectively, and angle of inclination of the base $\varphi$ with respect to its centre of gravity. Matrices of masses, damping and stiffness $M, C$ and $K$, respectively, are the symmetric. Vector $\Gamma=\left[\begin{array}{llll}-1 & 0 & 0 & 0\end{array}\right]^{T}$ defines the excitation force acting on the LCE. Equation (1) indicates that the mechanical system has four resonant modes. It should be mentioned that for the range of interesting vibrations, all four modes are not of interest. The typical Bode diagrams and simplified presentation of EMVF are given on Figure 2 [6-7]. The characteristic (1) refers to a complete model of resonant EMVF, while characteristic (2) refers to its simplified representation. The whole system is reduced to mass of moving material including masses of LCE and vibratory trough $m[\mathrm{~kg}]$, equivalent stiffness of composite springs $k \quad[\mathrm{~N} / \mathrm{m}]$ and equivalent coefficient of damping $b$ $[\mathrm{N} / \mathrm{m} / \mathrm{s}]$.

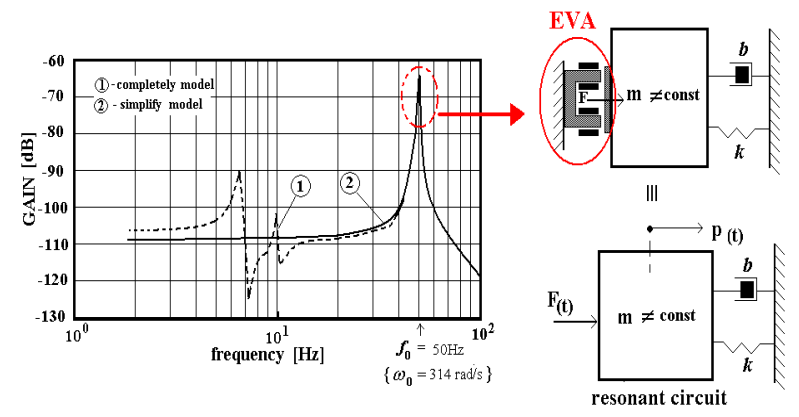

Figure 2. Typical amplitude - frequency characteristics and simplified presentation of resonant EMVF

In practical applications the largest contribution to moving the LCE has a dominant oscillatory mode, coming from high quality composite springs and related to the displacement $p[17]$ : 


$$
\ddot{p}+2 \xi \cdot \omega_{0} \dot{p}+\omega_{0}^{2}\left(p-p_{0}\right)=K_{p} \cdot \omega_{0}^{2} \cdot F
$$

If one considers movement around the equilibrium position $p=p_{0}$, (2) becomes:

$$
\ddot{p}+2 \xi \cdot \omega_{0} \dot{p}+\omega_{0}^{2} p=K_{p} \cdot \omega_{0}^{2} \cdot F .
$$

Where are: $\omega_{0}=\sqrt{k / m}$ - resonant frequency, relative damping factor $\xi=b / 2 m \omega_{0}$, and static gain $K_{p}=1 / k$.

The electromagnetic part is represented by the vibratory actuator EVA as the generator of the excitation force $F$ which is, through the electromagnetic field in the air gap between the inductor and armature, transferred to LCE. Detailed model of EVA, presented in [9], [13] and [17-19], in the form:

$$
\begin{gathered}
L(p) \cdot \frac{d i}{d t}+\left(\frac{\partial L(p)}{\partial p} \cdot \frac{d p}{d t}+R_{c}\right) \cdot i=u, \\
F=\frac{1}{2} \cdot \frac{\partial L(p)}{\partial p} \cdot i^{2} .
\end{gathered}
$$

Where $R_{c}$ represents active resistance and $L(p)$ inductance of EVA coil:

$$
L(p)=L_{0} \cdot \frac{p_{0}}{\varepsilon+p} .
$$

Quantities $i$ and $u$ represent the EVA current, and EVA voltage, respectively. The bronze disc with thickness $\varepsilon$ doesn't permit inductor to form a complete magnetic circuit of iron; in other words, it inhibits "gluing" of armature and inductor, which is undesirable. In the real cases is $\varepsilon<<p_{0}$. Mechanical force $F$ produced by the electromagnetic action of EVA coil acts on its armature which is a constituent part of LCE. If the short excitation current pulse for EVA is synchronized with the instant when the armature is passing through the equilibrium position, i.e. when $p=p_{0}$, inductance $L(p)$ can be represented, with sufficient accuracy, as $L(p) \approx L_{0}$. Now, (4) in the vicinity of the operating point can be represented as:

$$
L_{0} \cdot \frac{d i}{d t}+R_{c}^{\prime} \cdot i=u
$$

Parameter $R_{c}^{\prime}$, represents the equivalent resistance which is dependent on the speed of LCE $d p / d t$ and gradient of the coil inductance $\partial L / \partial p$ at the operating point $p=p_{0}$, and is given as:

$$
R_{c}^{\prime}=R_{c}+\left.\frac{d p}{d t} \cdot \frac{\partial L}{\partial p}\right|_{p=p_{0}}
$$

Based on (3) - (8) is formed a complete dynamic simulation model of the resonant EMVF. The simulation model is shown in Figure 3. It is clearly that the presented model is nonlinear, which is due to the nonlinear functions of EVA inductance, which is shown a functional block EVALUE3. Additional nonlinearity brings a functional block EVALUE4. Product $\dot{p} \cdot i \cdot \partial L(p) / \partial p$ represents counter electro motive force that is presented withe $(p, \dot{p}, t)$. This induced voltage opposes the voltage $u(t)$ that is applied to the terminal ends of the EVA.

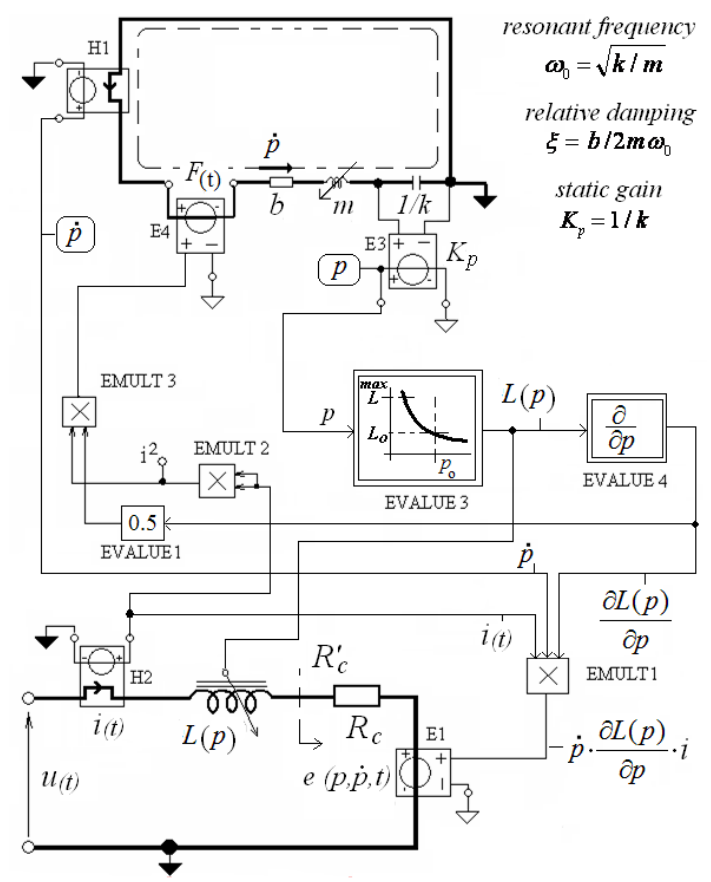

Figure 3. Complete simulation model of resonant EMVF

The model can be linearized around the operating point $p=p_{0}$. In this case, for small values of displacement $p$, EVA can be understood as a linear actuator whose inductance is $L\left(p_{0}\right) \approx L_{0}$. The presented simulation model has been adopted as a premise for the application of current control of EVA in vibration control of resonant EMVF.Tanking into account that the excitation current pulses of EVA are short (a few milliseconds), it can be assumed that the equivalent time constant $L_{0} / R_{c}^{\prime}$ is much longer than their duration. On the basis of this, it can be concluded that $R_{c}^{\prime} \cdot i<<u$. Therefore, member $R_{c}^{\prime} \cdot i$ in (7) can be neglected. Finally, the approximation of (7) is given by:

$$
\frac{d i}{d t}=\frac{u}{L_{0}} \text {. }
$$

As already mentioned, the pulse excitation is, from the energy point of view, the most suitable method of excitation of resonant EMVF. Owing to the predominantly inductive nature of EVA coil, indicated by (9), it is very simple, by applying a suitable transistor power converter and corresponding control [13], to generate triangular current pulses with changeable frequency and time duration.

\section{SWITCH MODE POWER CONVERTERS FOR VIBRATION CONTROL OF EMVF}

For most technical systems operation in the resonance range is unfavorable because it can lead to significant stresses and fracture of mechanical construction, since in this case, for small values of excitation forces, 
amplitude of oscillations get very large. The limitation of the significant amplitude oscillations can be achieved by appropriate control of excitation force of EMVF.

Application of the phase controlled SCR converters in vibration control of EMVF implies a fixed frequency of vibrations, imposed by the supply network frequency. A serious problem arises when the mass of the conveying material is changed, i.e. mechanical resonance of the system has changed. In such case the whole vibratory system will not operate efficiently. It is possible to tune amplitude but not the frequency of the vibrations. Variation of the mechanical resonance due to variation of the mass of the conveyed material, or even variation of the system parameters (characteristics of the springs, damping, etc.), leads to reduction of efficiency of the EMVF. In order to accomplish an optimal and efficient operation at a new resonant frequency, it is necessary to change the frequency of EVA coil current, rather the frequency of electromagnetic excitation force of the resonant EMVF.

Application of transistor switch mode power converters [12-13], [20-21], enables accomplishing the amplitude and/or frequency control of resonant EMVF. Their use makes the excitation of EMVF independent of the supply network frequency. In addition, the control of frequency ensures EMVF operation in the region of mechanical resonance (tracking and tuning of resonant frequency).

Figure 4 shows the simple switch mode topology of power converter for driving resonant EMVF. Figure 3(a) shows the basic topology which provides current power control which generates a triangular half-wave of EVA current with variable frequency and time duration. The Figure 3(b) show the characteristic waveforms (displacement $p$, EVA voltage $u(t)$, EVA current $i(t)$ and control voltage $V_{C}$ ). The rising of EVA current is achieved by short turn-on of power switch $\mathrm{Q}$. Then the voltage on the inductance of EVA coil is positive and equal $V_{0} / 2>0$. After power switch $\mathrm{Q}$ turning-off, the voltage on the inductance of EVA coil, becomes negative $\left(V_{0} / 2-V_{0}=-V_{0} / 2<0\right)$, and hence the decrease of the EVA current. Since the excitation force is proportional to the square of the current, it will be very close to the Dirac excitation pulses $\delta(t)$, as show on Figure 4(b).

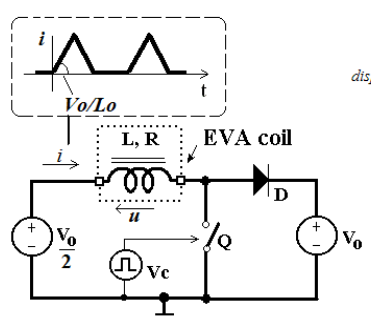

(a)

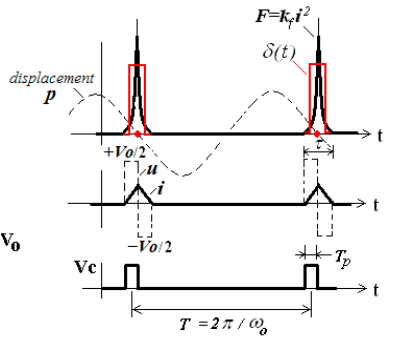

(b)
Figure 4. Switch mode power converter for driving resonant EMVF, (a) basic topology circuit, (b) characteristic waveforms

The detailed presentation previously described topology, including the principle diagram of the current control is shown in Figure 5. The control circuit which provides control of the amplitude, duration, and frequency of the triangular current half-wave is shown in Figure 5(a). The characteristic waveforms are shown in Figure 5(b). Obtaining the voltage $V_{0} / 2$ from input voltage $V_{0}$ is achieved by high frequency step-down ("buck") switching power converter which consists of: switch $Q_{1}$, diode $D_{1}$ and $L_{0} C_{0}$ filter.
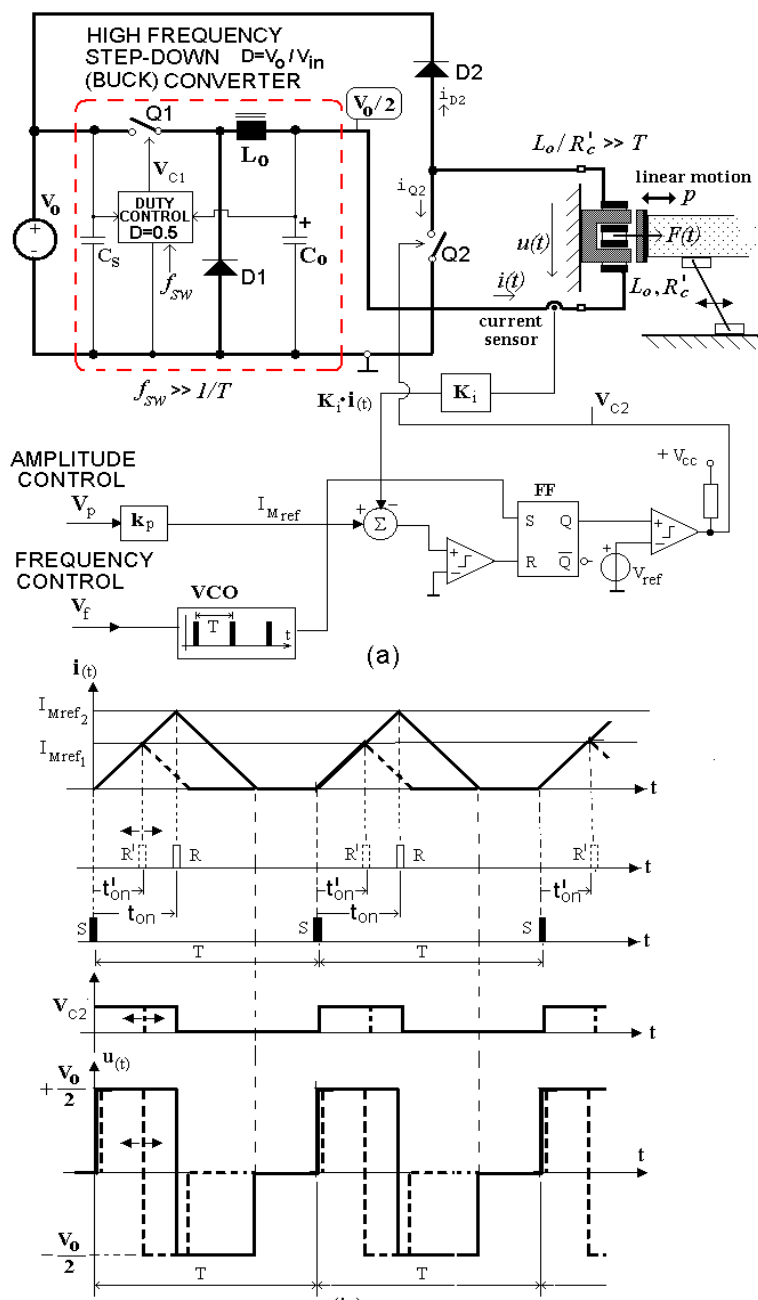

(b)

Figure 5. Programmed power current control of resonant EMVF; (a) basic topology circuit, (b) characteristic waveforms

The control circuit of this converter is based on duty-cycle control and maintaining the voltage ratio $D=V_{\text {out }} / V_{\text {in }}$ on the value 0.5 , i.e. for $V_{\text {in }}=V_{0}$ implies that $V_{0}=V_{0} / 2$. Instantaneous value of the actuator current $i(t)$ is measured by the corresponding current sensor. The measured signal is amplified by gain factor $K_{i}$ and the amplified signal is compared with the reference value $I_{\text {Mref }}$. This reference value determines the amplitude of EVA current and its time duration. Setting the RS flip-flop FF is accomplished from a voltage controlled oscillator (VCO). By signal pulse from the VCO to SET input of flip-flop FF, the state of logical "1" is established at its output $Q$, i.e. switch $Q_{2}$ is turned-on. This establishes the current through EVA coil in the form a rising ramp since voltage $V_{0} / 2$, is applied across the EVA coil terminals. The rising of current continues until the instantaneous current value 
reaches the reference value $I_{\text {Mref }}$, when the RESET pulse is generated at R input of flip-flop FF. In this case, the state of logical " 0 " is established at its output $Q$. As this state $Q_{2}$ is turned-off, and current of the coil is taken over by return diode $D_{2}$ (named "free welling"). EVA current decreases linearly since voltage $V_{0} / 2$ is applied at the coil terminals. The state of reset is maintained until a new SET pulse arrives from the oscillator. The amplitude and duration of the current are determined by the instant when instantaneous value of the current reaches value $I_{\text {Mref }}$. Since inductive resistance predominates, the rise time is approximately the same as the fall time. The time duration of the current half-wave is linear function of $I_{\text {Mref }}$. This means that tuning the amplitude of vibrations of the LCE is accomplished by tuning the value of $I_{\text {Mref }}$. As already mentioned, control of the frequency of vibrations is accomplished by tuning the frequency of the pulses setting flip-flop FF.

\section{SIMULATION RESULTS}

Based on a simulation model of the resonant EMVF in Figure 3 and the topology of power converter in Figure 5 (b) was formed the simulation circuit of the complete vibratory system. In this simulation circuit are implemented and then tested amplitude and frequency control of resonant EMVF. In simulations were set parameters that correspond to real EMVF system and real EVA. The most important parameters are given in Table 1.

Table 1. Parameters of vibratory feeding system

\begin{tabular}{|c|c|c|}
\hline \multicolumn{3}{|c|}{$\begin{array}{l}\text { MECHANICAL PARAMETERS of VIBRATORY } \\
\text { FEEDER }\end{array}$} \\
\hline $\begin{array}{l}\text { Mass of LCE without } \\
\text { material }\end{array}$ & $m_{k 0}[\mathrm{~kg}]$ & 1.15 \\
\hline $\begin{array}{l}\begin{array}{l}\text { Stiffness } \\
\text { elements } \\
\text { springs) }\end{array} \\
\end{array}$ & $k[\mathrm{~N} / \mathrm{mm}]$ & 113.50 \\
\hline Relative damping factor & $\xi$ & $\begin{array}{l}0.01- \\
0.1\end{array}$ \\
\hline $\begin{array}{l}\text { Change mass of load } \\
\text { material }\end{array}$ & $\Delta m_{k}[\mathrm{~kg}]$ & 0.306 \\
\hline \multicolumn{3}{|c|}{ ELECTRO-MECHANICAL PARAMETERS of EVA } \\
\hline $\begin{array}{l}\text { Inductance at equilibrium } \\
\text { position }\end{array}$ & $L_{0}[\mathrm{H}]$ & 0.40 \\
\hline Resistance of coil & $R_{C}[\Omega]$ & 30.0 \\
\hline $\begin{array}{l}\text { Air gap in equilibrium } \\
\text { position }\end{array}$ & $p_{0}[\mathrm{~mm}]$ & 5.00 \\
\hline Thickness of bronze disc & $\varepsilon[\mathrm{mm}]$ & 0.30 \\
\hline
\end{tabular}

Figure 6 shows the simulation results related to the amplitude control, at the unchanged mechanical resonant frequency of $f_{0}=44.45 \mathrm{~Hz}$ (completely filled trough of EMVF or total mass $m_{k}=m_{k o}+\Delta m_{k}=1.456 \mathrm{~kg}$ and stiffness $k=113.5 \mathrm{~N} / \mathrm{mm}$ ). The excitation (driving) frequency of current pulses $f_{d r v}$ is set to a value $f_{0}$, that is, their period is the amounted to $T=1 / f_{0}=22 \mathrm{~ms}$. In Figure 6 (a) shows the simulation results for the case when the amplitude of the triangular waveform of excitation current EVA was $I_{M r e f 1}=0.5 A$, and its duration of $\tau_{1} \approx 2 \mathrm{~ms}$. In this way, was obtained the value of the amplitude of oscillations of $P_{m 1}=0.7 \mathrm{~mm}$, or the value vibratory width ("peak to peak" amplitude) $2 P_{m 1}=1.4 \mathrm{~mm}$. In Figure 6 (b) shows the case where the amplitude of the current was $I_{M r e f 2}=1 \mathrm{~A}$, and time duration $\tau_{2} \approx 4 \mathrm{~ms}$. In this case was obtained amplitude $P_{m 2}=1.4 \mathrm{~mm}$, or vibratory width $2 P_{m 2}=2.8 \mathrm{~mm}$
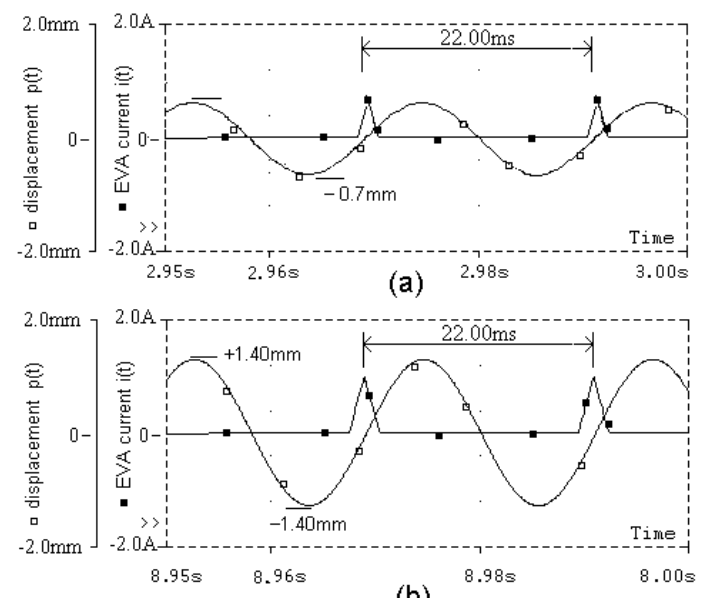

(b)

Figure 6. Amplitude control of resonant EMVF at mechanical resonant frequency $f_{0}=44.45 \mathrm{~Hz}$ amplitude/duration of EVA current $0.5 \mathrm{~A} / 2 \mathrm{~ms}$, (b) amplitude/duration of EVA current $1 \mathrm{~A} / 4 \mathrm{~ms}$

Figure 7 presents results of a simulation related to the frequency control of the resonant EMVF. Observed variables that are of interest vibratory displacement and EVA current, are given in three characteristic cases. In Figure 7 (a) shows the characteristics waveforms for the case of the established resonant at the unloaded resonant EMVF (empty vibratory trough), i.e. $m_{k}=m_{k 0}$. In this case excitation (driving) frequency was equal to resonant frequency i.e. $f_{d r v}=f_{01}=50 \mathrm{~Hz}$. In Figure 7 (b) shows typical waveforms for the case of loaded vibratory trough $\left(m_{k}=m_{k o}+\Delta m_{k}=1.456 \mathrm{~kg}\right)$, wherein the excitation frequency is remains unchanged value of $f_{d r v}=50 \mathrm{~Hz}$. In this case, the resonant frequency amounted to $f_{02}=44.45 \mathrm{~Hz}$. It is clearly seen that the amplitude of oscillations significantly decrease compared to the previous resonant mode. Maintaining the amplitude of the oscillation can be achieved by reducing the value of the excitation frequency to value $f_{d r v}=f_{02}=44.45 \mathrm{~Hz}$. Simulation results for this case are given in Figure 7 (c). Based on the presented simulation results, it can be concluded that the current pulse excitation of EVA provides continuous sinusoidal function of vibratory displacement.

From the spectral point of view, a triangular EVA current excitation is characterized by a high harmonic content (the fundamental harmonic $\omega_{0}$ plus higher harmonics at frequencies $2 \omega_{0}, 3 \omega_{0}$, etc...). In view of (5), the excitation force is proportional to the square 
current, i.e. $F=k \cdot i^{2}$, and it is concluded that it will contain the same harmonic spectrum.
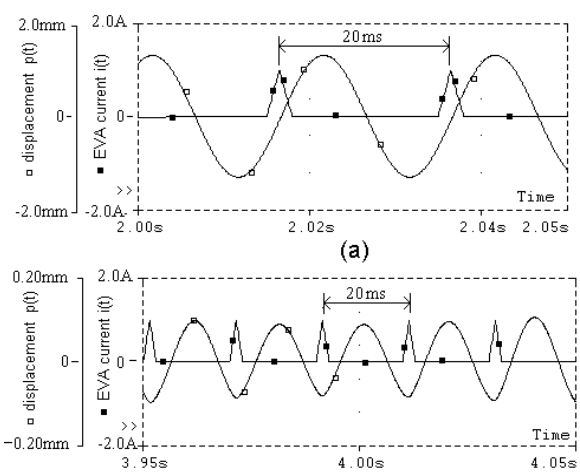

(b)

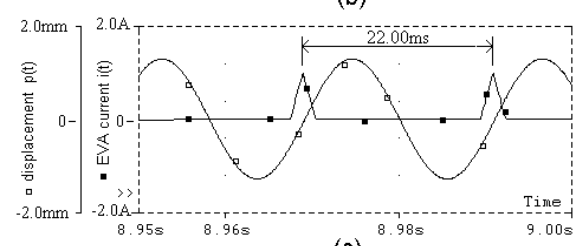

(c)

Figure 7. Frequency control of resonant EMVF;

(a) $f_{d r v}=f_{01}=50 \mathrm{~Hz}$ (empty vibratory trough),

(b) $f_{d r v}=50 \mathrm{~Hz}>f_{02}=44.45 \mathrm{~Hz}$ (filled vibratory trough),

(c) $f_{d r v}=f_{02}=44.45 \mathrm{~Hz}$ (new resonant regime)

However, irrespective of the pulse excitation of LCE, the output displacement $p$ is a "smooth" sinusoid, as a consequence of the character of the mechanical part of the system, which, according to (3), attenuates higher harmonics for frequencies $\omega>\omega_{0}$, as shown in Figure 2 .

\section{PRACTICAL REALISATION}

A practically realized power converter for excitation of a resonant EMVF is described in this section. Figure 8shows block diagram of the complete system of vibratory control. Power converter is really consists of three power converter: (1) front end high frequency AC/DC converter with power factor correction (PFC) control, (2) DC/DC link converter with duty-cycle control (step-down or "buck" converter) and (3) low frequency IGBT converter with triangle pulsating output current for driving EVA.

The namely "front end" AC/DC converter is in fact a controllable transistor PFC rectifier with twin "boosts" stages (two MOSFET's and two boost diode) and inductance $L_{\text {in }}$ on the side of power mains $230 \mathrm{~V}, 50 \mathrm{~Hz}$. This converter with advantages over the conventional PFC (diode bridge rectifier-power switch-diodeinductance on DC side) is described in detail, in [2223]. PFC converter is in fact pre-regulator which stabilize mains AC maims voltage $230 \mathrm{~V}$ to $400 \mathrm{VDC}$. The voltage $400 \mathrm{VDC}$ is input voltage of DC/DC link „step-down" converter with duty-cycle control. Main components of this power stage are: MOSFET powers switch Q1, free-willing diode D1 and $L_{0} C_{0}$ filter. Driving the MOSFET Q1 is realized by a ,floating” drive circuit which can sustain high voltage and is immune to sharp voltage edges $(d v / d t)$. Duty-cycle $D$ is maintained to value $D=0.5$, so that the output voltage of this converter is $V_{o}=D \cdot V_{\text {in }}=400 / 2=200 \mathrm{VDC}$.

The output converter for excitation of EVA coil realized using the IGBT power switch Q2 and return diodes D2. This diode return accumulated electrical energy (energy accumulated during rising current-ON time) from inductance of EVA coil to input capacitor $C_{i n}$, placed to the DC output of PFC rectifier.

The current controller is realized with circuit shown in Figure 5(a), in the discrete technology. The value of EVA current is measured by a Hall Effect based current sensor (LEM current sensor). Reference inputs of current controller are $V_{f}$ (reference frequency) and $I_{\text {Mref }}$ reference amplitude of EVA current. Also, the current controller includes overload and short circuit protection. The ,intervening" system of protection is applied. Under normal conditions, the load current is programmed by the current controller. In the case of a direct short circuit or overload, protection circuit takes over.

The vibratory control (amplitude and /or frequency control) is based on industrial PC104 module where the algorithms for search and tracking of the resonant frequency are implemented, together with reference input signals for current controller (adjusting the amplitude and frequency of the EVA current pulses). Measurement of the output displacement of the LCE and detection of its passage through the equilibrium position $\left(p=p_{0}\right)$ is accomplished by a non-contact inductive displacement sensor, operating in the displacement range $\pm 5 \mathrm{~mm}$ and frequency range $0-1 \mathrm{kHz}$. The signal of this sensor is transmitted by an electronic amplifier and normalized to the input level $0-5 \mathrm{~V}$ (analogue input AI1 of PC104 module). Vibratory amplitude $P_{m r e f}$ is set to analogue input $\mathrm{AI} 2$.

\section{EXPERIMENTAL RESULTS}

The experimental results are obtained with a realized laboratory prototype of the resonant EMVF, where the amplitude-frequency control has been applied. In the experiments the measured quantities of interest were: EVA current $i(t)$, EVA voltage $u(t)$ and displacement of LCE $p(t)$.

The influence of variations of the amplitude and time duration of the EVA current pulses on the LCE displacement at excitation frequency equal to resonant frequency $f_{d r v}=f_{0}=44.5 \mathrm{~Hz} \rightarrow T=22.5 \mathrm{~ms}$ is shown in Figure 9. Figure 9(a) presents the oscilloscope records of EVA current and LCE displacement for the reference value of the current $I_{\text {Mref } 1}=0.5 \mathrm{~A}$. Under these conditions, time duration of the current pulses was approximately $\tau_{1}=2 \mathrm{~ms}$, while the accomplished vibratory width of the output displacement of LCE was $2 P_{m 1}=1.4 \mathrm{~mm}$. Figure $9(\mathrm{~b})$ shows the records of EVA current and LCE displacement for the reference value of the current $I_{M r e f 2}=1.0 \mathrm{~A}$. Under these conditions, duration of the current pulses was approximately $\tau_{2}=4 m s$, while the accomplished vibratory width of the output displacement of LCE was $2 P_{m 2}=2.8 \mathrm{~mm}$. 


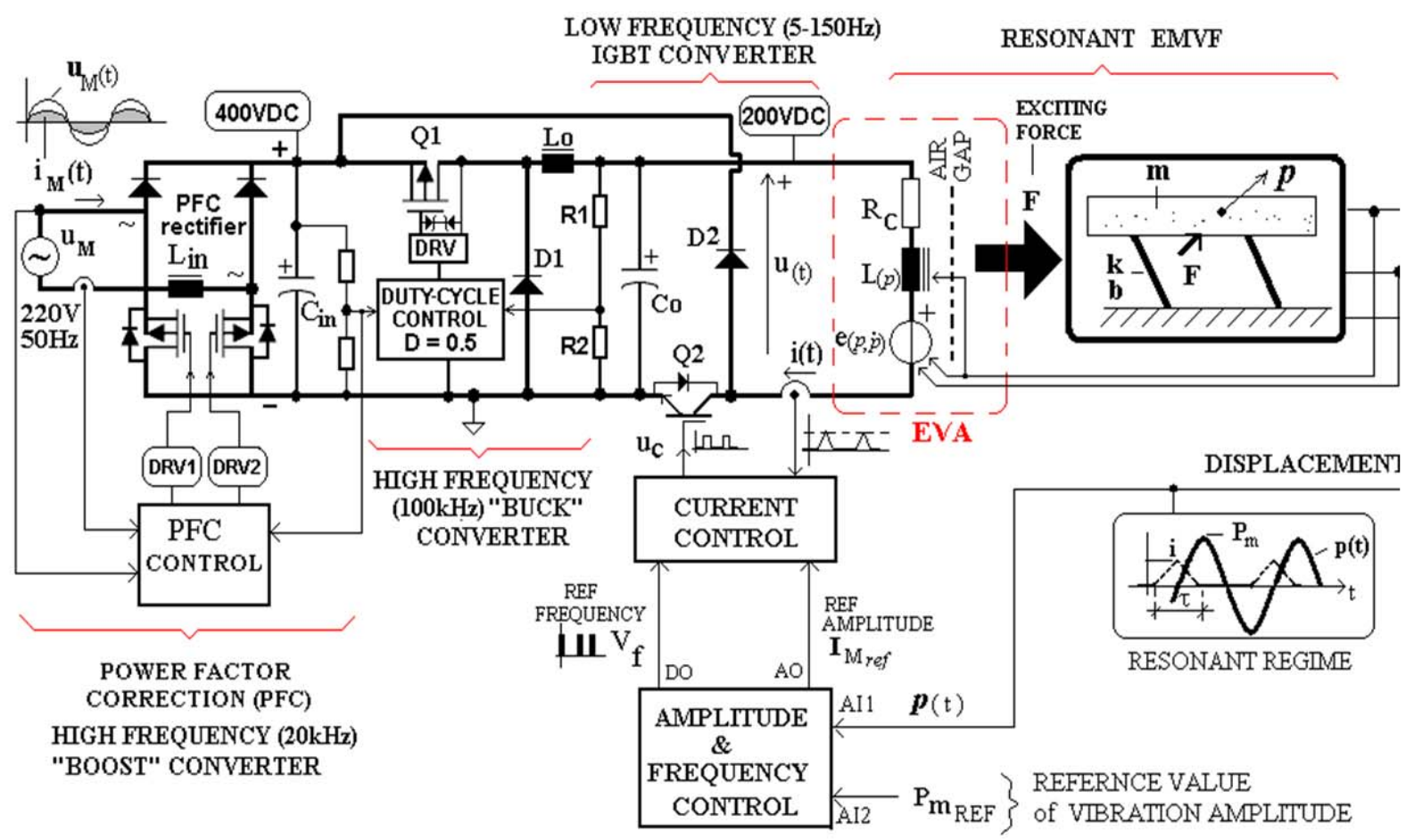

Figure 8. Block scheme practical realized system for vibratory control of resonant EMVF

The presented experimental results in Figure 9, relate to amplitude control of resonant EMVF, are fully consistent with simulation results presented in Figure 6.
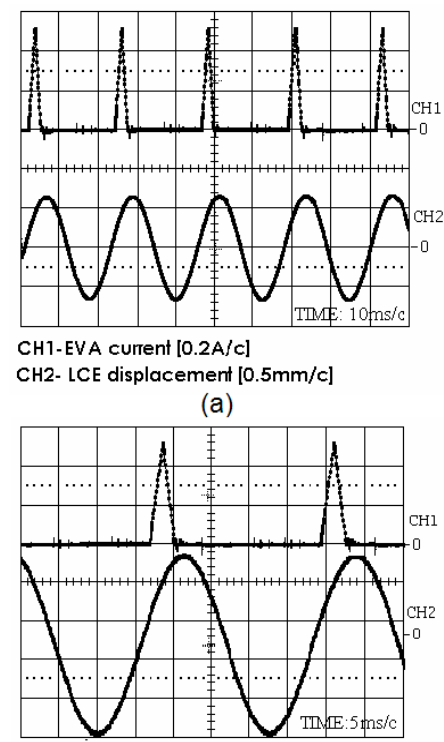

CH1-EVA current $[0.4 \mathrm{~A} / \mathrm{c}]$

CH2- LCE displacement $[0.5 \mathrm{~mm} / \mathrm{c}$

(b)

Figure 9. Amplitude control of real resonant EMVF at resonant frequency $f_{0}=44.5 \mathrm{~Hz}$, EVA voltage $\pm 200 \mathrm{~V}$ (a) LCE displacement $\pm 0.7 \mathrm{~mm}$, (b) LCE displacement $\pm 1.4 \mathrm{~mm}$

Figure 10 shows the compensation of the disturbance caused by a mass change of LCE load. In this loading process are presented the oscilloscopic records of LCE displacement and EVA current. At the time moment marked with arrow- $\uparrow$, LCE was suddenly filled (with sugar material mass of $\Delta m_{k}=300 \mathrm{~g}$ ) at driving frequency $f_{d r v 1}=50 \mathrm{~Hz}$. Under these conditions, the mechanical resonance frequency of the system is changed from $f_{01}=50 \mathrm{~Hz}$ to $f_{02}=44.5 \mathrm{~Hz}$. LCE was vibrated with significant reduced peak to peak amplitude. The maintenance of amplitude of oscillations of LCE and compensation of disturbance are achieved with almost unchanged amplitude of EVA current, but with change of its driving frequency from $f_{d r v 1}=50 \mathrm{~Hz}$ to $f_{d r v 2}=44.5 \mathrm{~Hz}$. Detailed oscilloscopic records of LCE displacement, EVA current and EVA voltage for interesting times intervals $\Delta t_{1}$ and $\Delta t_{3}$, are given on Figure 11 and Figure 12, respectively.

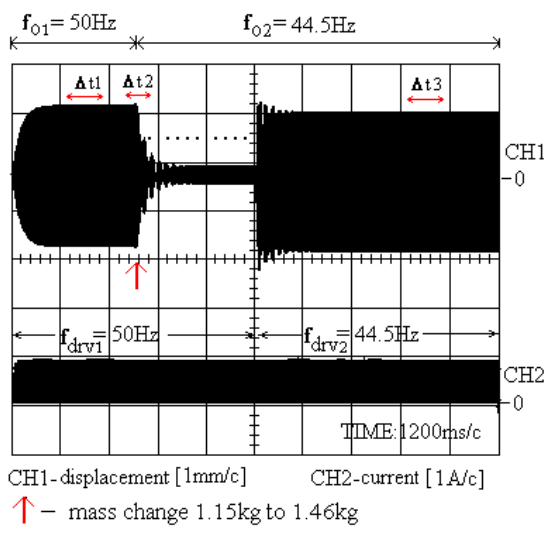

Figure 10. Frequency control of resonant EMVF and change mass compensation

The oscilloscopic records in Figure 11, corresponding time interval $\Delta t_{1}$, in which is driving frequency equal to mechanical resonant frequency i.e. $f_{d r v 1}=f_{01}=50 \mathrm{~Hz}$. The reference value of the current 
was $I_{\text {Mref } 1}=1.0 \mathrm{~A}$. Under these conditions, time duration of the current pulses was approximately $\tau_{1}=4 \mathrm{~ms}$, while the accomplished vibratory width of the output displacement of LCE was $P_{m 1}=1.5 \mathrm{~mm}$ (vibratory width $2 P_{m 1}=3 \mathrm{~mm}$ ).

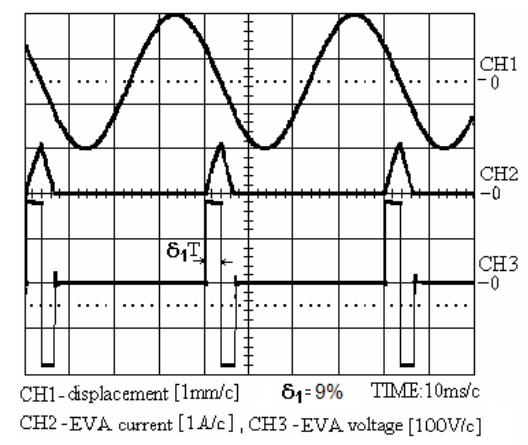

Figure 11. Frequency control of resonant EMVF: detailed scope of time interval $\Delta t_{1}$

Figure 12 shows the characteristics oscilloscopic records for time interval $\Delta t_{3}$ in which is driving frequency equal to new mechanical resonant frequency (after loading of LCE with sugar material $\Delta m_{k}=300 \mathrm{~g}$ ) i.e. $f_{d r v 2}=f_{02}=44.5 \mathrm{~Hz}$. The reference amplitude value of the EVA current has remained unchanged i.e. $I_{\text {Mref } 1} \approx I_{\text {Mref } 2}$. Also, time duration is remained about the same, but due to frequency control, and monitoring and adjusting the excitation frequency to the new resonance frequency, is achieved maintaining the vibratory amplitude to the value $P_{m 2}=1.5 \mathrm{~mm}$ (vibratory width $2 P_{m 1}=3 \mathrm{~mm}$ ).

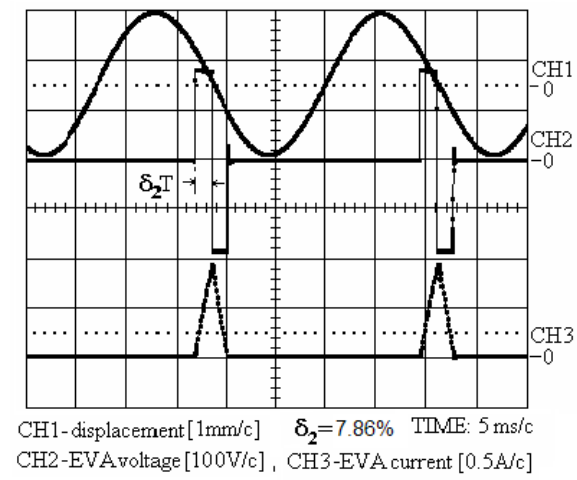

Figure 12. Frequency control of resonant EMVF: detailed scope of time interval $\Delta t_{3}$

The presented experimental results in Figures 11 and 12, relate to frequency control of resonant EMVF, are fully consistent with simulation results presented in Figures 7(a), and 7(c), respectively.

\section{CONCLUSIONS}

The most significant contribution of this research is a development of an optimal control for the electromagnetic resonant vibratory feeder and an increase of theirs energy efficiency. There has been achieved a compensation of required resonant regime and change resonant frequency. Dominating influences are: changing of conveying material mass, changing stiffness of flexible element, variation of mains voltage supply. With proposed method of vibratory control of resonant EMVF are achieved number advantages:

-freedom to operate a resonant EMVF with any resonant frequency from $5 \mathrm{~Hz}$ to $150 \mathrm{~Hz}$ (frequency control)

-proposed vibratory controller will continually search for the natural frequency of the EMVF(resonance) and excite it at that frequency (active tuning); in the located natural (resonant) frequency, it is possible to tune amplitude and time duration of the EVA coil current i.e. amplitude oscillations of the LCE (amplitude control)

-flexible automation with minimum change-over time because electronics replace the comprehensive and the complicated calibrations and mechanical settings

-vibratory drive can operate nondependent on mains frequency $(50 \mathrm{~Hz}$-Europe or $60 \mathrm{~Hz}-\mathrm{North}$ America) without changing the flexible springs and balancing masses (manual retuning process)

The presented simulations and experimental results which relate to proposed amplitude and frequency control are shown that regulated resonant EMVF drive provide high energy efficiency: minimum EVA coil current, minimum EVA coil heating, minimum supply current, minimum power consumption, input power factor correction.

\section{ACKOWLEDGEMENT}

This investigation has been carried out with the financial support of the Serbian Ministry of Education, Science and Technological Development, within technological development projects: TR33022 and TR35046.

\section{REFERENCES}

[1] Goncharevich, I.F., Frolov, K.V. and Rivin, E.I.: Theory of vibratory technology, Hemisphere Publishing Corporation, New York, 1990.

[2] Parameswaran, M.A. and Ganapathy .S.: Vibratory Conveying-Analysis and Design: A Review, Mechanism and Machine Theory, Vol. 14, No. 2, pp. 89-97, April 1979.

[3] Dyr, T. and Wodzinski, P.: Model particle velocity on a vibrating surface, Physicochemical Problems of Mineral Processing, Vol. 36, pp. 147-157, May 2002.

[4] Sloot, E. M. and Kruyt, N. P.: Theoretical and experimental study of the conveyance of granular materials by inclined vibratory conveyors, Powder Technology, Vol. 87, No. 3, pp. 203-210, 1996.

[5] Frei, P.U.: An Intelligent Vibratory Conveyor for the Individual Object Transportation in Two Dimensions, Proceedings of the 2002 IEEE/RSJ, Intl. Conference on Intelligent Robots and Systems, EPFL, Lausanne, Switzerland, pp.1832-1837, October 2002.

[6] Doi, T., Yoshida, K., Tamai, Y., Kono, K., Naito, K. and Ono, T.: Modelling and Feedback Control for Vibratory Feeder of Electromagnetic Type, 
Journal of Robotics and Mechatronics, Vol. 11, No. 5, pp. 563-572, June 1999.

[7] Doi,T.,Yoshida, K., Tamai, Y., Kono, K., Naito, K. and Ono, T.: Feedback Control for Electromagnetic Vibration Feeder, JSME International Journal, Series C, Vol. 44, No. 1, pp. 44-52, 2001.

[8] Babitsky,V.I.: Autoresonant Mechatronics Systems, Mechatronics 5, pp. 483-495, 1995.

[9] Despotovic, Z.V., and Stojiljkovic, Z.V.: Power converter control circuits for two-mass vibratory conveying system with electromagnetic drive: Simulations and experimental results, IEEE Trans. Ind. Electron., Vol. 54, No. 1, pp.453-466, Feb. 2007.

[10] Despotović, Ž.V., Ribić, A. I., Terzić, M.V.: A Comparison of Energy Efficiency of SCR Phase Control and Switch Mode Regulated Vibratory Conveying Drives, Proceedings of IX Symposium Industrial Electronics INDEL 2012, Banja Luka, Vol.1, pp.103-110, November 2012.

[11] Sokolov, I.J., Babitsky, V.I., Halliwell, N.A., Autoresonant Vibro-impact System with Electromagnetic Excitation, Journal of Sound and Vibration, 308 , pp. 375-391, 2007.

[12] Mohan, N., Undeland, T. M. and Robbins,W. P., Power Electronics-Converters, Applications and Design, John Wiley\&Sons, INC., New York, 1995.

[13] Despotović, Ž.V., Ribić, A. I., Sinik, V.: Power Current Control of a Resonant Vibratory Conveyor Having Electromagnetic Drive, Journal of Power Electronics, Vol.12, No4, July 2012.

[14] Cock, H.G.: Vibratory Feeders, PHILIPS Technical Review, Vol.24, pp.84-95, May 1975.

[15] Han L. and Tso, S.K.: Mechatronic design of a flexible vibratory feeding system, Proceedings of the I MECH-E- Part B Journal of Engineering Manufacture, Vol.217, No.6, pp.837-842, June 2003.

[16] Wolfsteiner, P., Pfeiffer, F.: Dynamics of a vibratory feeder, PROCEEDINGS of DETC '97, ASME Design Engineering Technical on References, Sacramento, California, DETC97/VIB3905, pp.1-9, Sept.14-17, 1997.

[17] Ribic, A.I. and Despotovic, Z.V.: HighPerformance Feedback Control of Electromagnetic Vibratory Feeder, IEEE Transaction on Industrial Electronics, Vol.57, Issue:9, pp.3087-3094, Aug. 2010.

[18] Despotović, Ž.V., Jović, M.: Mathematical model of electromagnetic vibratory exciter with incremental motion, Proceedings of XIII International Scientific - Professional Symposium INFOTEH®-JAHORINA 2014, Vol.13, pp.91-96, March 2014.

[19] Seely, S., Electromechanical energy conversion, McGraw-HILL Book Company INC., New York, 1962.
[20] Rashid, M. H., Power Electronics, Prentice-Hall Englewood Cliffs, New York, 1988.

[21] Thorborg, K., Power Electronics, Prentice Hall International (UK) Ltd. 1988.

[22] Martinez, R. and Enjeti, P.N., A High Performance Single Phase Rectifier with Input Power Factor Correction, IEEE Trans. Power Electron., Vol.11, No.2, pp.311-317, Mar. 1996.

[23] Ferrari de Souza, A. and Barbi, I., A New ZVSPWM Unity Power Factor Rectifier with Reduced Conduction Losses, IEEE Trans. Power Electron. , Vol.10, No.6, pp.746-752, Nov.1996.

\section{КОНТРОЛА РЕЗОНАНТНИХ ЕЛЕКТРОМАГНЕТНИХ ВИБРАЦИОНИХ ДОДАВАЧА}

\section{Жељко В. Деспотовић, Милан Лечић, Милан Р. Јовић, Ана Ђурић}

Вибрациони додавачи са електромагнетном побудом, односно електромагнетни вибрациони додавачи (ЕМВД) су најчешће коришћени у процесној индустрији за обезбеђење гравиметријског протока ситнозрних и расутих материјала. Ови погони обезбеђују лаку и једноставну контролу масеног протока транспортујућих материјала. $\mathrm{y}$ поређењу са осталим погонима (пнеуматским, инерционим, центрифугалним, итд.), они су једноставније и компактније конструкције, робусни и поуздани у раду. Одсуство хабајући механичких делова као што су редуктори, кишници, ексцентри и сл., чине ЕМВД веома економичном опремом. Стандардни претварачки излазни степени намењени за контролу ЕМВД су базирани на СЦР елементима (тиристорима и тријацима). Њихово коришћење подразумева коришћење контроле фазног угла (КФУ) и стога константну учестаност вибрација. На овај начин контролно коло мора бити синхронизовано са мрежном учестаношћу 50(60)Х3. Уз помоћ КФУ је једино могуће остварити подешавање амплитуде вибрација, али не и њихове учестаности. Примена прекидачких транзисторских (ИГБТ или МОСФЕТ) енергетских претварача, омогућава амплитудску и (или) фреквентну контролу ЕМВД. Њихово коришћење подразумева побуду ЕМВД независно од мрежне учестаности. Додатно, фреквентна контрола дозвољава рад у области механичке резонанце. Рад у овој области је веома ефикасан, пошто је могуће обезбедити значајне излазне помераје, веома малом улазном снагом. Оптималан и ефикасан рад захтева праћење резонантне учестаности. У овом раду су представљени једно могуће решење вибрационе контроле ЕМВД, као и одговарајући симулациони и експериментални резултати. 